\title{
Using Processed Feeds For Laying Quails (Coturnix coturnix japonica)
}

- Author(s)
Murakami $\mathrm{AE}^{1}$
Souza $\mathrm{LMG}^{1}$
Sakamoto $\mathrm{MI}^{2}$
Fernandes $\mathrm{JIM}^{3}$
1 Departamento de Zootecnia - PPZ/UEM.
Maringá, PR.
2 Departamento de Zootecnia - FZEA/USP.
Pirassununga, SP.
3 Departamento de Zootecnia - UFPR.
Palotina, PR.

\section{Mail Address}

Alice Eiko Murakami

Universidade Estadual de Maringá

Centro de Ciências Agrárias

Programa de Pós-Graduação em Zootecnia

Avenida Colombo, 5790

Bloco J45, Sala 14, Zona 07

87.020-900. Maringá, PR, Brazil

E-mail: aemurakami@uem.br

\section{Keywords}

Egg quality, processing, production performance.

\section{ABSTRACT}

The aim of this experiment was to determine the productive performance and egg quality of Japanese quails fed different types of processed rations (mash, extruded, or pelleted). One hundred and fortyfour 18-w-old quails (Coturnix coturnix japonica) were housed in galvanized wire cages and fed a $21.50 \%$ CP and $2850 \mathrm{kcal} \mathrm{ME} / \mathrm{kg}$ basal feed supplied in mash, extruded, or pelleted form. Experimental data were analyzed by ANOVA as a complete randomized design, with three treatments (ration forms) and six replicates of eight quails each. When necessary, means were compared by Tukey's test at 5\% significance. Quails fed pelleted feed presented higher egg production, feed intake, and egg mass weight as compared to mash- and extruded-diet-fed birds. Under the conditions of the present experiment, it was possible to conclude that the feed physical form did not affect egg quality, except for pelleted diets, which promoted good production performance and high egg mass. However, the use of feed pelleting should be economically analyzed considering the final cost of egg production.

\section{INTRODUCTION}

All-mash feed is the typical physical form of layer diets. However, pelleted, ground, or extruded processed feed may increase layer productivity by reducing feed loss, preventing selective feeding, increasing feed nutritional density, improving feeding program characteristics, and destroying pathogenic microorganisms from feedstuffs (Behnke, 1992).

The supply of ground/pelleted feeds as alternatives to mash physical form is currently used as a method to obtain higher feed intake by layers, and consequently, better body weight gain and feed conversion ratio (Botura, 1997).

Despite the growth of quail egg market, breeding and nutrition of Japanese quails (Coturnix coturnix japonica) have received little attention from researchers, and are mainly based on producer expertise. In addition, there are few scientific evidences on the benefits of the physical processing of laying quail feeds in literature. Ariki et al. (1996) studied the effect of processed feeds on the performance and quality of laying hen eggs, and verified that birds need to be adapted to the processed diet before the production period. Production parameters were not influenced by feed physical form, except for egg weight.

According to Furlan et al. (1998), time of digesta transit in the quail intestine is very fast, which impairs nutrient digestibility. In addition, this parameter is related to diet composition, feed intake level, and to diet physical form (Leandro et al., 2001).

In this context, the present trial aimed at determining the performance and egg quality of laying quails fed different types of processed feeds (mash, pelleted, or extruded). 
Murakami AE, Souza LMG, Sakamoto MI, Fernandes JIM

\section{MATERIALS AND METHODS}

The experiment was performed at the poultry house of Iguatemi Experimental Farm of Maringá State University. One hundred forty four 18-w-old quails were evaluated for 63 days, during three laying period of 21 days. Maximum and minimum average temperatures were $32{ }^{\circ} \mathrm{C}$ and $20^{\circ} \mathrm{C}$, respectively.

Birds were housed in $38 \times 25 \times 14 \mathrm{~cm}$ battery cages equipped with a nipple drinker and a trough feeder. A complete randomized experimental design, with three treatments ( 3 feed physical forms: mash, pelleted, and extruded) and six replicates of 8 quails each, was applied.

Basal feed was formulated taking into account feedstuff composition, as suggested by Rostagno et al. (2000) (Table 1). After mixing, one third of the feed was pelleted, one third was extruded, whereas the last third remained in the mash form. Both processed feeds were then ground to achieve a particle size that is accepted by quails, i.e., $1 \mathrm{~mm}$ geometric diameter.

\begin{tabular}{|c|c|}
\hline \multicolumn{2}{|c|}{$\begin{array}{l}\text { Table } 1 \text { - Ingredient and calculated composition of the basal } \\
\text { feed. }\end{array}$} \\
\hline Feedstuffs & $\%$ \\
\hline Corn & 53.73 \\
\hline Soybean meal - $45 \%$ & 36.98 \\
\hline Limestone & 5.30 \\
\hline Soybean oil & 1.89 \\
\hline Dicalcium phosphate & 1.33 \\
\hline Salt & 0.35 \\
\hline Vitamin premix ${ }^{1}$ & 0.25 \\
\hline Mineral premix ${ }^{1}$ & 0.07 \\
\hline DL - Met $(99 \%)$ & 0.09 \\
\hline $\mathrm{BHT}^{2}$ & 0.01 \\
\hline TOTAL & 100.00 \\
\hline \multicolumn{2}{|c|}{ Composition, calculated } \\
\hline $\mathrm{ME},(\mathrm{kcal} / \mathrm{kg})$ & 2850 \\
\hline$C P,(\%)$ & 21.50 \\
\hline $\mathrm{Ca}(\%)$ & 2.50 \\
\hline Available P (\%) & 0.36 \\
\hline Met + Cys (\%) & 0.76 \\
\hline Lys (\%) & 1.16 \\
\hline $\mathrm{Cl}(\%)$ & 0.24 \\
\hline $\mathrm{Na}(\%)$ & 0.18 \\
\hline \multicolumn{2}{|c|}{ 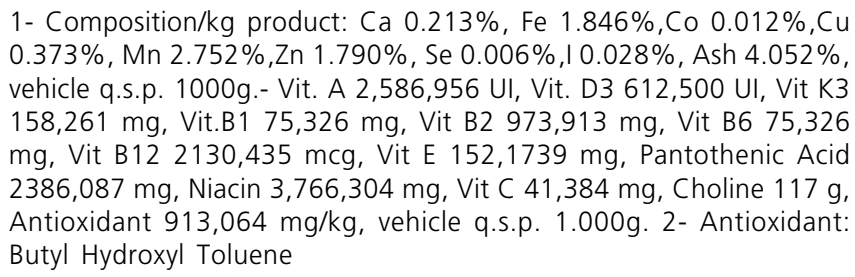 } \\
\hline
\end{tabular}

Birds were submitted to artificial light immediately after sunset, receiving a total of $17 \mathrm{~h}$ of light daily. Feed and water were provided ad libitum during the entire experimental period.
Using Processed Feeds For Laying Quails (Coturnix coturnix japonica)

Feed intake and feed conversion ratio ( $\mathrm{kg}$ feed/ dozen eggs and $\mathrm{kg}$ feed/kg eggs) data were obtained every 21 days. Egg production per replicate was daily recorded to calculate total egg production per experimental group during three 21-d cycles.

Internal and external egg qualities were evaluated during the last four days of each production period, All intact eggs from each replicate were individually identified, and weighed on a precision scale $(0.01 \mathrm{~g})$. A sample of three eggs per replicate was used to determine eggshell thickness and Haugh Units.

Eggshells were washed, dried at environmental temperature for $72 \mathrm{~h}$, and then individually weighed for determination of shell weight relative to egg weight.

Eggshell thickness was measured at three points equally distant from the central part of the eggshell using a manual micrometer (Mitutoyo ${ }^{\circledR}$ ).

Egg Haugh unit was determined by measuring albumen height as the distance between external albumen border and yolk of broken eggs placed on a flat glass surface, using a manual micrometer. Albumen height was correlated to weight, as suggested by Brant et al. (1951), according to the following equation:

\section{Haugh Units $=100 \log (H+5.57-1.7$ W0.37 $)$}

$$
\begin{aligned}
& \text { Where: } \mathrm{H}=\text { albumen height }(\mathrm{mm}) \text {; } \\
& \mathrm{W}=\text { egg weight }(\mathrm{g}) \text {. }
\end{aligned}
$$

The obtained data were submitted to analysis of variance (ANOVA), and means were compared by Tukey's test at $5 \%$ of significance with the aid of SAEG (1998) software.

\section{RESULTS AND DISCUSSION}

Quail performance and egg quality results are presented in Table 2. Processed feeds affected ( $p>0.05)$ egg production, egg mass, and daily feed intake. As compared to the groups fed mash and extruded feeds, quails fed the pelleted feed presented higher egg production and mass weight. This may be attributed to improved diet digestibility caused by the process of pelletization, which changes the tertiary structure of proteins, favoring their digestion, and increasing amino acid availability for egg production (Vargas et al., 2001). However, these results are not consistent with those reported by Ariki et al. (1996), who did not observe any differences in egg production or feed intake of layers fed processed diets. In addition, those authors verified detrimental effects of the 
extruded feeds on eggshell percentage and thickness, which was not detected in the present experiment.

\begin{tabular}{|c|c|c|c|c|}
\hline \multirow{2}{*}{ Characteristics } & \multicolumn{4}{|c|}{ Feed physical form } \\
\hline & Mash & Extruded & Pelleted & CV (\%) \\
\hline Egg production (\%) & $72.91 \mathrm{C}$ & $81.26 b$ & $90.53 a$ & 5.24 \\
\hline Daily feed intake $(\mathrm{g})$ & $23.23 b$ & $24.25 b$ & $27.07 a$ & 6.54 \\
\hline Feed conversion $(\mathrm{kg} / \mathrm{kg}$ ) & 2.674 & 2.738 & 2.579 & 5.22 \\
\hline Feed conversion ( $\mathrm{kg} / \mathrm{dz}$ egg) & 0.388 & 0.359 & 0.362 & 5.53 \\
\hline Egg weight (g) & 11.16 & 10.93 & 11.37 & 3.00 \\
\hline Egg mass $(g)$ & $7.84 \mathrm{c}$ & $8.86 b$ & $10.52 a$ & 4.63 \\
\hline Haugh Units & 93.31 & 93.30 & 93.40 & 1.17 \\
\hline Eggshell thickness $(\mathrm{mm})$ & 0.248 & 0.247 & 0.241 & 3.79 \\
\hline Eggshell yield (\%) & 7.70 & 7.57 & 7.83 & 2.71 \\
\hline
\end{tabular}

Values sharing no common letters in the same row are significantly different by Tukeys's test at $5 \%$ of probability.

The higher daily feed intake of quails fed the pelleted diet may be attributed to an enhancement of feed palatability and digestibility (Nakage et al., 2002), as pelletization improves nutrient digestibility due to the mechanical action, and the temperature and humidity employed in the process. Flemming et al. (2002) also observed higher feed intake of broilers fed pelleted feed as compared to a mash-fed group, as well as Parsons et al. (2006) with growing chickens.

According to López \& Baião (2004), pelleted feed determines increase in feed intake and prevents the selection of large particles. Amerah et al. (2007), testing diet particle size and processing, observed higher weight gain and feed intake, as well as better feed conversion in broilers fed pelleted diets as compared to those fed mash diets. The authors suggested that this increase in feed intake was due to an improvement in dietary starch digestibility. The temperature used for pelleting, if adequately controlled, promotes partial starch gelatinization, solidifies protein, and favors the action and the access of the endogenous enzymes, promoting higher diet digestibility. In addition, pelleted feeds require less physical efforts to ingest them, with consequent lower energy expenditure by birds. According to Nilipour (1993), pelleted feeds results in higher feed intake, because it does not allow particle selection by the birds, as pelleting promotes better aggregation of the diet components, avoiding nutrient imbalance and feedstuff segregation during feed transportation and handling. In addition, pelleting increases feed physical density anddecreases feed volume with better adjustment to bag space, dust, and feed intake time by the bird, consequently improving feed efficiency.

The pelleting process may present some economical disadvantages, such as higher production costs and reduction of the stability of some vitamins and/or enzymes added to the feeds (Nilipour, 1993). However, some benefits on bird performance are attributed to the use of pelleting, such as improvement of the digestibility of some nutrients, lower feed waste (Ávila et al., 1995; Maiorka, 1998), prevention of particle selection (Cherry, 1982), lower feed microbiological contamination (Nilipour, 1993), feed efficiency improvement, and higher egg production (Almirall et al., 1997) as compared to mash diets.

\section{CONCLUSION}

Under the conditions of the present experiment, it was possible to conclude that the physical form of the feed did not affect egg quality; however, it promoted better quail performance and higher egg mass. Nevertheless, the decision to pellet feeds must be economically analyzed taking into account the final cost of egg production.

\section{REFERENCES}

Almirall M, Cos R, Esteve-Garcia E, Brufau J. Effect of inclusion of sugar beet pulp, polluting and season on laying hen performance. British Poultry Science 1997; 38:530-536.

Amerah AM, Ravindran V, Lentle RG, Thomas DG. Feed Particle size: implication on the digestion and performance of poultry. Word's Poultry Science Journal 2007; 63:439-455.

Ariki J, Murata LS, Schocken-Iturrino RP, Araújo WA, Yabuta SS, Moraes VMB, Sakomura NK. Comparação entre rações processadas no desempenho e qualidade dos ovos de poedeiras comerciais. Anais da 33th Reunião Anual da SBZ; 1996; Fortaleza, CE. Brasil: SBZ; 1996. p.31-34.

Ávila VS, De Rosa PS, Rutz F. Efeito da forma física da ração sobre a composição bromatológica da carcaça de frangos de corte criados no verão. In: Anais da Conferência APINCO de Ciência e Tecnologia Avícolas; 1995; Curitiba, PR. Brasil: Curitiba: FACTA; 1995. p. $211-$ 212.

Behnke KC. Fatores que afectam la calidad del pelet. Mexico: Associación Americana de Soya; 1992.

Botura AP. Efeito da forma física da ração e características de carcaça de frangos de corte fêmeas criados no período de inverno [dissertação]. Pelotas (RS): Universidade Federal de Pelotas; 1997.

Brant AW, Otte AW, Norris KH. Recommended standards for scoring and measuring opened egg quality. Food Technology 1951; 5: 356-361.

Cherry JA. Non-caloric effects of dietary fat and cellulose on the voluntary feed consumption of White chickens. Poultry Science 
$1982,61: 345-350$

Flemming JS, Montanhini Neto R, Arruda JS, Franco SG. Efeito da forma física e do valor de energia metabolizável da dieta sobre o desempenho de frangos de corte. Archives of Veterinary Science 2002; 7(2):27-34.

Furlan AC, Andreotti MO, Murakami AE, Scapinello C, Moreira I, Fraiha M, Cavalieri RB. Valores energéticos de alguns alimentos determinados com codornas japonesas (Coturnix coturnix japonica). Revista Brasileira de Zootecnia 1998; 27(6):1147-1150.

Leandro NSM, Stringhini JH, Café MB. et al. Efeito da granulometria do milho e do farelo de soja sobre o desempenho de codornas japonesas. Revista Brasileira de Zootecnia 2001; 30(4):1266-1271.

López CAAA, Baião NC. Efeitos do tamanho da partícula e da forma física da ração sobre o desempenho, rendimento de carcaça e peso dos órgãos digestivos de frangos de corte. Arquivo Brasileiro de Medicina Veterinária e Zootecnia 2004; 56(2):214-221.

Maiorka A. Efeito da forma física e do nível de energia da ração em dietas formuladas com base em aminoácidos totais e digestíveis sobre o desempenho e a composição de carcaça de frangos de corte, machos, dos 21 aos 42 dias de idade [dissertação]. Porto Alegre (RS): Universidade do Rio Grande do Sul, Faculdade de Agronomia; 1998.

Nakage ES, Cardozo JP, Pereira GT, Queiroz SA, Boleli IC. Efeito da forma física da ração sobre a porosidade, espessura da casca, perda de água e eclodibilidade em ovos de perdiz (Rhynchotus rufescens). Revista Brasileira de Ciência Avícola 2002; 4(3):227-234.

Nilipour A. La peletización mejora el desenpeño? Industria Avícola 1993; 9(12):42-46.

Parsons AS, Buchanan NP, Blemings ME, Wilson ME, Moritz JS. Effect of corn particle size and pellet texture on broiler performance in the growig phase. The Journal of Applied Poultry Research 2006: 15(2):245-255.

Rostagno HS, Albino LFT, Donzele JL, Gomes PC, Ferreira AS, Oliveira RF, Lopes DC. Tabelas brasileiras para aves e suínos: composição de alimentos e exigências nutricionais. Viçosa: UFV; 2000. 141p.

SAEG. Sistema para análises estatísticas e genéticas: Versão 8.0. Viçosa: Fundação Arthur Bernardes; 1998.

Vargas GD, Brum PAR, Fialho FB, Rutz F, Bordin R. Efeito da forma física da ração sobre o desempenho de frangos de corte machos. Revista Brasileira de Agrociência 2001; 7(1):42-45. 